\title{
Synthesis of some substituted pyrimidines via cycloaddition reaction of amidines and chalcones
}

\author{
M. S. Al-Ajely G. T. Sedeek \\ Department of Chemistry \\ College of Education \\ H. M. Al-Ajely \\ Department of Chemistry \\ College of Science \\ University of Mosul
}

Received
$03 / 04 / 2008$
Accepted

$22 / 07 / 2008$

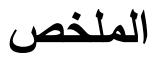

تم في هذا البحث تحضير الام ديلات (1 و r r) من خلال تفاعل كل من كحول البنزايل

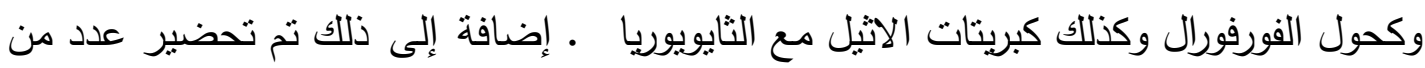

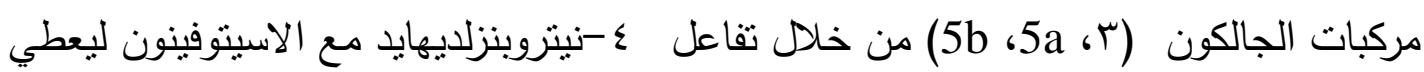

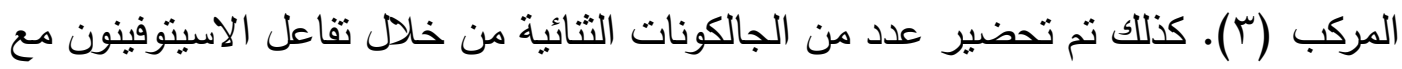

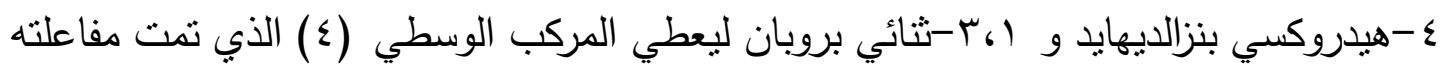

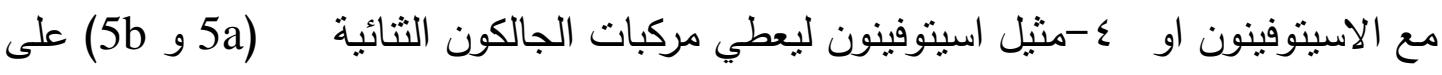

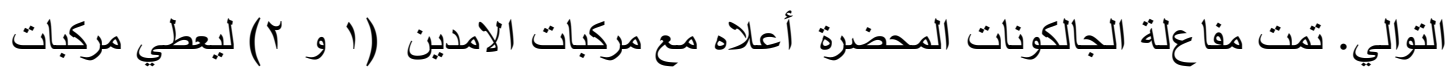

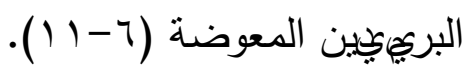

تم تتخيص المركبات المحضرة من خلا طيف الأثعة تحت الحمراء IR.

\section{ABSTRACT}

Substituted amidines $(1,2)$ where prepared from the condensation of benzyl, furfuryl alcohols and ethyl sulphate with thiourea. Chalcone compounds $(3,5 \mathrm{a}$ and $5 \mathrm{~b})$ where also prepared from condensation of 4nitrobenzaldehyde to give compound (3) while acetophenone, 4-hydroxy benzaldehyde and 1,3-dibromopropane gave the diformyl intermediate (4) then it was underwent further reaction with either acetophenone or 4methyl acetophenone to afford compounds (5a,5b) respectively. Condensation of the above amidines with the resulted chalcones or dichalcones afforded the substituted pyrimidines (6-11).

Their structures confirmation were studied by IR and were discussed. 


\section{INTRODUCTION}

Azarifar and Shacbanzadeh ${ }^{(1)}$ prepared a number of chalcones by condensing substituted 1-acetyl naphthalene with naphthaldehyde in ethanolic solution. The Chalcones themselves were prepared in high temperature water without any use for base or acid catalysis ${ }^{(2)}$, and treated the later with hydrazine derivatives to obtain the corresponding pyrazolines. Different pyrazolines ${ }^{(3-8)}$ and bis pyrazolenes ${ }^{(9,10)}$ have been synthesized in good to excellent yields from the precursor chalcones and bis-chalcones with suitable reagents. Pyrimidine derivatives have been prepared from the reaction of chalcones and amidines ${ }^{(11,12)}$. On the other hand 2-amino-4-(2,4-dichalcon-5-flurophenyl)-6-aryl pyrimidines were also prepared from substituted chalcones and quanidine ${ }^{(13)}$. Transchalcones represent an important class of compounds employed as such for their luteratiy antineoplastic, spasmolytic, antibiotic, bacterostatic and bactericidal properties ${ }^{(14)}$ or due to their chemical flexibility, as synthons for the production of five and six-membered ring systems ${ }^{(15)}$.

Some researchers studied the biochemical characterization and mutational of a chalcone synthesized from yellow snapdragou (Antirrhinum majus). According to the abover importance of chalcones, we investigate the reaction of new series of amidates and some new synthesized chalcones to afford new derivatives of pyrimidines.

\section{EXPERIMENTAL}

Melting points were determined using Electrothermal 9300 melting point apparatus (uncorrected). I.R. spectra was recorded by infrared spectrophotometer model Tensor 27 Bruker Co. using $\mathrm{KBr}$ discs.

\section{Synthesis of 5-benzyl isothioronium chloride $(1 \mathrm{a})^{(16)}$}

A mixture of $(0.24$ mole $)$ of benzyl chloride and $(0.24$ mole $)$ of thiourea in $20 \mathrm{ml}$ of ethanol was refluxed carefully for 30 minutes, during which time a vigorous reaction takes place the resulting homogeneous solution was cooled and the precipitated solid was recrystallized from ethanol. The product is melts at $(172-174){ }^{\circ} \mathrm{C}$ with yield of $95 \%$ (Lit. m.p. $\left.=172-174{ }^{\circ} \mathrm{C}\right)$.

\section{Synthesis of 5-ethyl thioronium sulfate (1b) $)^{(17)}$}

A mixture of (1.0 mole) thiourea and $(0.55$ mole $)$ of diethyl sulfate was heated in an oil bath at a temperature of about $\left(130-140{ }^{\circ} \mathrm{C}\right)$ a vigorous exothermic reaction starts and the temperature of the mixture was held below $180{ }^{\circ} \mathrm{C}$ heating was continued at temperature of 170-180 ${ }^{\circ} \mathrm{C}$ for 2 hours and the cooled product was titurated with a mixture of ethanol and ether to remove excess diethyl sulfate yield (80\%), m.p. $=97-$ $99^{\circ} \mathrm{C}$ (Lit. $\left.=95-97{ }^{\circ} \mathrm{C}\right)$. 
Synthesis of S-2-furfuryl isothiouream chloride $(1 \mathrm{c})^{(18)}$

In round bottomed flask was placed $(0.5$ mole) of thiourea and ( 5 $\mathrm{ml})$ of water and $(4 \mathrm{ml})$ of concentrated hydrochloric acid, the solid was dissolved by gentle heating and the solution was cooled to $30{ }^{\circ} \mathrm{C}$. (0.5 mole) furfuryl alcohol was added to the reaction mixture. The reaction which usually commences spontaneously within a few minutes was strongly exothermic and should be controlled by suitable cooling with tap water so as to hold the temperature near $60{ }^{\circ} \mathrm{C}$ when the reaction subsides cooling was discontinued and the clear dark green solution was allowed to stand at room temperature for 12 hours to obtain solid product with yield of $(93 \%)$, m.p. $>300{ }^{\circ} \mathrm{C}$.

\section{Synthesis of pyridino amidine hydrochloride $(2)^{(19)}$}

A flask containing ( 0.058 mole) of 3-cyanopyridine dissolved in 50 $\mathrm{ml}$ of dry chloroform and (0.065 mole) of absolute ethyl alcohol was cooled to $0{ }^{\circ} \mathrm{C}$ while dry hydrogen chloride saturates the reaction mixture the contents were allowed to stand at $\left(0{ }^{\circ} \mathrm{C}\right)$ for $16 \mathrm{hrs}$., and then poured into a separatory funnel containing enough of ice-cold $50 \%$ sodium hydroxide solution to give an alkaline solution. The mixture was shaken vigorously and the chloroform layer separated, washed with water until neutral, dried over potassium carbonate and concentrated to give the crude imidate. The later was dissolved $75 \%$ aqueous ethanol containing (0.0224 mole) of ammonium chloride and heated at $70{ }^{\circ} \mathrm{C}$ for $4 \mathrm{hrs}$., charcoal filtered and diluted with 2-3 volume of acetone. The unreacted ammonium chloride that separated was filtered and the filtrate was again diluted with acetone until the cloud point. After standing for several hours at $0{ }^{\circ} \mathrm{C}$, the product was separated as colourless needles with melting point of $190{ }^{\circ} \mathrm{C}$ and $78 \%$ yield.

\section{Synthesis of 4-nitrobenzal acetophenone $(3)^{(20)}$}

Acetophenone (1.2 gm, 0.01 mole) dissolved in $(3 \mathrm{ml})$ ethanol. The mixture was added to a solution of (1.5 gm, 0.01 mole $)$ of $\mathrm{p}$ nitrobenzaldehyde in $(3 \mathrm{ml})$ ethanol, $(5 \mathrm{ml})$ of $10 \% \mathrm{NaOH}$. The final mixture was stirred for 24 hours at room temperature. Then it was filtered off, washed with water till neutralization, dried and purified by recrystallization from ethanol, yield (89\%), m.p. $=159-161{ }^{\circ} \mathrm{C}$.

\section{Synthesis of 1,3-bis (4-formyl phenoxy) propane $(4)^{(21)}$}

A mixture of 4-hydroxy benzaldehyde (24.4 gm, 0.2 mole). 1,3Dibromopropane (18.7 gm, 0.1 mole) and anhydrous potassium carbonate $(60 \mathrm{gm})$ in absolute ethanol $(150 \mathrm{ml})$ was refluxed with stirring for six hours. The cold mixture was poured onto water, solid materials 
immediately was obtained. The desired product was filtered off, washed several times with water and cold ethanol, dried and recrystallized from ethanol to afford a white crystals yield $(88 \%)$, m.p. $=118-120^{\circ} \mathrm{C}($ Lit. $=$ $\left.119-120{ }^{\circ} \mathrm{C}\right)$.

\section{Synthesis of 1,3-bis (phenoxy propyl)-4,4'-bis chlacone $(5 \mathbf{a}, \mathbf{b})^{(22)}$}

1,3 -Bis (4-formyl phenoxy) propane $(0.134 \mathrm{gm}, 0.001 \mathrm{~mole})$ was dissolved in ethanol $(5 \mathrm{ml})$ and added to the solution of $(0.002$ mole $)$ of an appropriate acetophenones in ethanol $(5 \mathrm{ml})$ and $(2 \mathrm{ml})$ of $(4 \%$ ethanolic $\mathrm{NaOH}$ ). The mixture was stirred for 24 hours (at room temperature). Then the mixture was solidified and the pale yellow chalcones were separated by suction filtration, washed with ethanol and water to neutralize, dried and purified by recrystallization from ethanol. Yield $(78 \%)$, m.p. $=196-197{ }^{\circ} \mathrm{C}, 177-179{ }^{\circ} \mathrm{C}$ for compounds $\mathrm{a}$ and $\mathrm{b}$ respectively.

General procedure for the synthesis of 4-aryl-6-phenyl or tolyl-2-Ssubstituted thio or (3-pyridyl) pyrimidine (6a-c), (7a-c), (8a-c) and (911) respectively ${ }^{(11)}$

Sodium carbonate $(0.2 \mathrm{gm})$ was added to vigorous stirred solution of substituted amidine hydrochloride (2 mole) in $(20 \mathrm{ml})$ DMSO the mixture was stirred at $20{ }^{\circ} \mathrm{C}$ for $10 \mathrm{~min}$. The chalcones $(3,5 \mathrm{a}, \mathrm{b})(1 \mathrm{~mole})$ was added. The reaction mixture was heated at $80{ }^{\circ} \mathrm{C}$ for $18 \mathrm{hrs}$. with an air stream bubbled through. The melting points and IR data were showed in Table (1). 


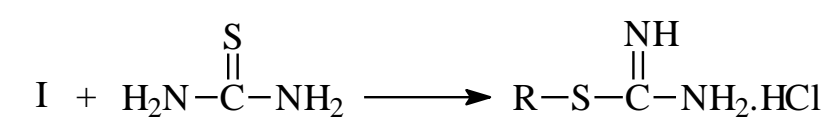

(a-c)

$\begin{array}{ll}\mathrm{Ia}=\mathrm{PhCH}_{2} \mathrm{OH} & 1 \mathrm{a}, \mathrm{R}=\mathrm{PhCH}_{2}- \\ \mathrm{Ib}=\left(\mathrm{C}_{2} \mathrm{H}_{5}\right)_{2} \mathrm{SO}_{4} & 1 \mathrm{~b}, \mathrm{R}=\mathrm{C}_{2} \mathrm{H}_{5}- \\ \mathrm{Ic}= & 1 \mathrm{c}, \mathrm{R}=\end{array}$

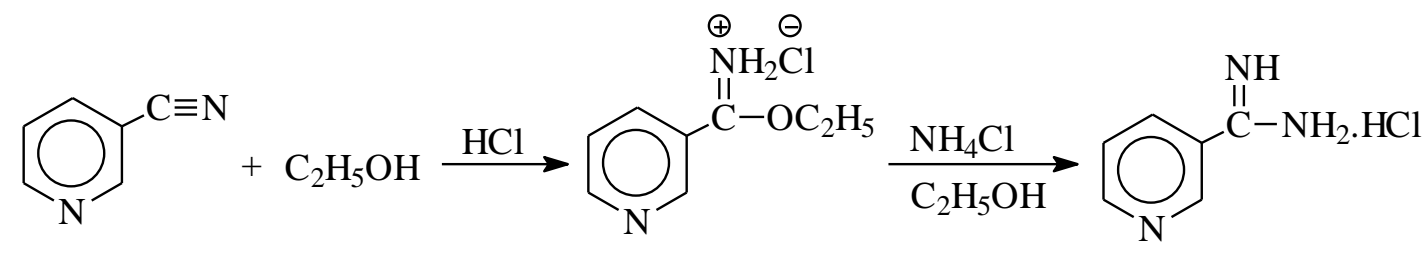

II

III<smiles>C[CH+]C(=O)c1ccc([N+](=O)[O-])cc1</smiles>

IV

V

(3)

$2 \mathrm{HO}-O \stackrel{\mathrm{O}}{\mathrm{C}}-\mathrm{H}+\mathrm{Br}-\left(\mathrm{CH}_{2}\right)_{3}-\mathrm{Br} \longrightarrow \mathrm{H}-\stackrel{\mathrm{O}}{\mathrm{C}} \longrightarrow-\mathrm{O}-\left(\mathrm{CH}_{2}\right)_{3}-\mathrm{O}-O \stackrel{\mathrm{O}}{\mathrm{C}}-\mathrm{H}$

VI VII

(4)<smiles>[X]c1ccc(C(C)=O)cc1</smiles><smiles>[X]c1ccc(C(=O)C=Cc2ccc(OCCOc3ccc(C=CC(=O)c4ccc([X])cc4)cc3)cc2)cc1</smiles>

$\mathrm{X}=\mathrm{H},(5 \mathrm{a})$

$(5 a, b)$

$\mathrm{X}=\mathrm{CH}_{3},(5 b)$

Scheme (1) 


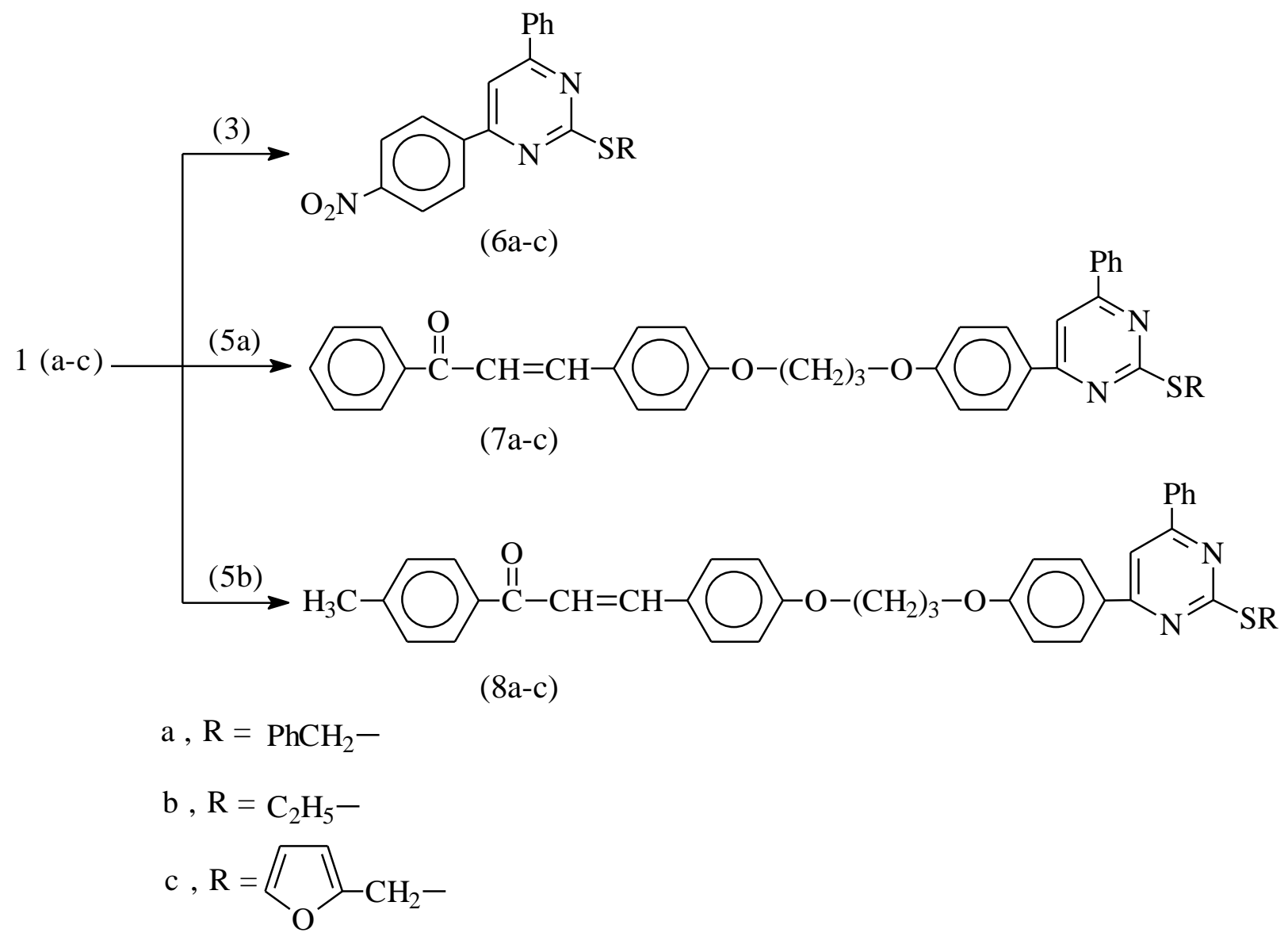

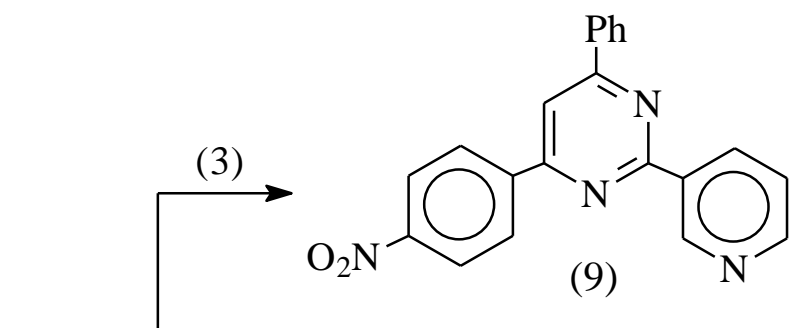

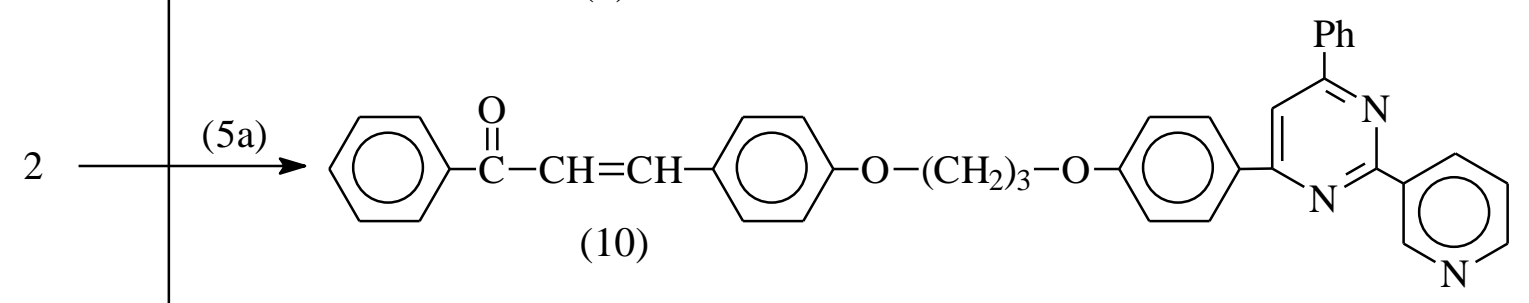

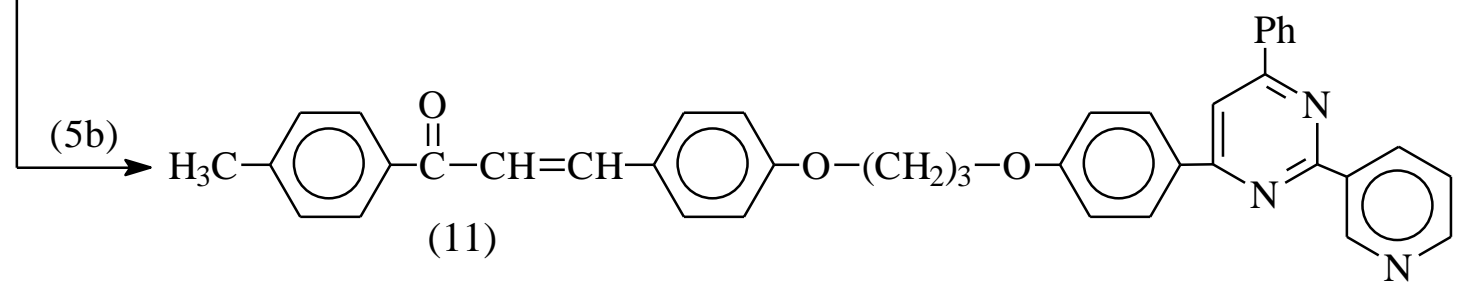

Scheme (2) 
Table (1): The melting points, yields and IR spectral data for compounds (6-11)

\begin{tabular}{|c|c|c|c|c|c|c|}
\hline \multirow{2}{*}{$\begin{array}{l}\text { Comp. } \\
\text { No. }\end{array}$} & \multirow{2}{*}{$\begin{array}{l}\text { m.p. } \\
\left({ }^{\circ} \mathrm{C}\right)\end{array}$} & \multirow{2}{*}{$\begin{array}{l}\text { Yield } \\
(\%)\end{array}$} & \multicolumn{4}{|c|}{ IR $v \mathrm{~cm}^{-1}$} \\
\hline & & & $\mathrm{C}-\mathrm{O}$ & $\mathrm{C}=\mathrm{C}$ & 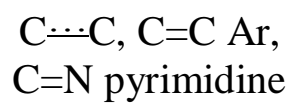 & $\mathrm{C}=\mathrm{O}$ \\
\hline $6 a$ & $92-94$ & 76 & - & 1659 & 1528,1573 & - \\
\hline $6 b$ & $116-118$ & 80 & - & 1639 & 1528,1570 & - \\
\hline $6 \mathrm{c}$ & $142-144$ dec. & 78 & - & 1636 & 1450,1508 & - \\
\hline $7 \mathrm{a}$ & 180-182 dec. & 80 & 1114 & 1630 & 1456,1509 & 1650 \\
\hline $7 b$ & $126-128$ & 90 & 1173 & 1602 & 1480,1509 & 1657 \\
\hline $7 \mathrm{c}$ & $122-124$ & 79 & 1174 & 1600 & 1470,1509 & 1653 \\
\hline $8 \mathrm{a}$ & $106-108$ & 85 & 1114 & 1596 & 1456,1509 & 1650 \\
\hline $8 \mathrm{~b}$ & $175-177$ & 70 & 1173 & 1601 & 1464,1570 & 1660 \\
\hline $8 \mathrm{c}$ & $235-237$ & 82 & 1115 & 1601 & 1508,1573 & 1660 \\
\hline 9 & $108-110$ & 75 & 1108 & 1595 & 1448,1516 & 1653 \\
\hline 10 & $176-178$ & 83 & 1115 & 1600 & 1445,1572 & 1661 \\
\hline 11 & $220-222$ dec. & 87 & 1115 & 1601 & 1465,1573 & 1611 \\
\hline
\end{tabular}

\section{RESULTS AND DISCUSSION}

The amidine hydrochlorides 1a-c Scheme (1) were prepared as it was stated in the experimental part, their melting points were checked with the published literature ${ }^{(16-18)}$. Compound (2) was prepared from the corresponding nitrile and ethanol using the published procedure ${ }^{(19)}$.

Chalcone 3 (Scheme 1) was characterized by its IR absorption peaks exhibited at $1446,1516 \mathrm{~cm}^{-1}$ for $\mathrm{C}=\mathrm{C}$ aromatic ring carbon stretching bands while the $\mathrm{C}=\mathrm{O}$ and $\mathrm{C}=\mathrm{C}$ for the $\alpha, \beta$-unsaturated carbonyl system absorbed at $1659,1608 \mathrm{~cm}^{-1}$ respectively. Compound (5a) showed the following IR absorption bands 1474 and $1510 \mathrm{~cm}^{-1}$ related to the aromatic, $\mathrm{C}=\mathrm{C}$ alkene at $1632 \mathrm{~cm}^{-1}, \mathrm{C}=\mathrm{O}$ at $1686 \mathrm{~cm}^{-1}$. Compound 5a also showed the following absorption bands, 1510, 1572 $\mathrm{cm}^{-1}$ belong to $\mathrm{C}=\mathrm{C}$ stretching vibration, $1660 \mathrm{~cm}^{-1}$ for $\mathrm{C}=\mathrm{C}$ stretching of alkene, $1696 \mathrm{~cm}^{-1}$ for $\mathrm{C}=\mathrm{O}$ stretching vibration of $\alpha, \beta$-unsaturated system.

Compound (4) was prepared according to the published procedure ${ }^{(21)}$. This compound was characterized by the +ve Tollens test and -ve test for halogen using sodium fusion test. While its IR exhibited $\mathrm{C}-\mathrm{O}$ stretching absorption band at $1115 \mathrm{~cm}^{-1}, \mathrm{C}=\mathrm{O}$ stretching absorption at $1712 \mathrm{~cm}^{-1}$.

Compounds (1a-c) (Scheme 2) were allowed to undergo a condensation reaction with the 4-nitro chalcone compound (3) resulted into the formation of compounds (6a-c). Their IR spectral data (Table 1) showed the $\mathrm{C}=\mathrm{N}, \mathrm{C}=\mathrm{C}$ for the aromatic ring between $1528-1573 \mathrm{~cm}^{-1}$, while the $\mathrm{C}=\mathrm{C}$ for pyrimidine ring absorbed in the range of 1595-1659 $\mathrm{cm}^{-1}$.

Compound (1a-c) underwent equimolar condensation reaction with the dichlacone $5 \mathrm{a}, 5 \mathrm{~b}$ resulted into the formation of compounds (7a-c) and (8a-c) respectively. 
Compounds (7a-c) (Scheme 2), Table 1, characterized by the following absorption bands $\mathrm{C}-\mathrm{O}, \mathrm{C}=\mathrm{C}$ aromatic, $\mathrm{C}=\mathrm{C}$ for both unreacted chalcone moiety and the pyrimidine ring bands. Whole the carbonyl absorption region as indicated in the Table absorbed within the range of $1650-1657 \mathrm{~cm}^{-1}$.

In compounds (8a-c), the same observations were found for the $\mathrm{C}-\mathrm{O}$, $\mathrm{C}=\mathrm{C}, \mathrm{C}=\mathrm{N}$ of pyrimidine and the aromatic stretching bands together with the unreacted chalcone moiety. The presence of the unreacted $\alpha, \beta$ unsaturated system was confirmed from the IR absorption bands for compounds 7 and 8 within the region $1596-1630 \mathrm{~cm}^{-1}$ for $\mathrm{C}=\mathrm{C}$ and 1650 $1660 \mathrm{~cm}^{-1}$ for $\mathrm{C}=\mathrm{O}$ stretching vibrations. Supporting test was performed using 2,4-dinitrophenyl hydrazine which gives +ve test for both series of compounds 7 and 8 indicating the presence of this group within the structure of the above compounds. Elemental test for sulfur also indicates the presence of this element within the structure of these compounds.

The chalcone compound (3) was also allowed to undergo a condensation reaction with the corresponding amidine (2) revailed into the formation of compound (9) which is also characterized by the IR absorption bands for $\mathrm{C}-\mathrm{O}, \mathrm{C}=\mathrm{C}$, aromatic and $\mathrm{C}=\mathrm{N}$ pyrimidino, $\mathrm{C}=\mathrm{C}$ and $\mathrm{C}=\mathrm{O}$ of the unreacted chalcone moiety as indicated in Table (1).

Compounds 10 and 11 (Scheme 2) were also formed as a result of the condensation of equimolar of the dichalcones $(5 a, b)$ with the corresponding amidine hydrochloride (2). These substituted pyrimidines were characterized by the IR absorption groups $\mathrm{C}-\mathrm{O}, \mathrm{C}=\mathrm{C}$ of aromatic and $\mathrm{C}=\mathrm{N}$ pyrimidine, $\mathrm{C}=\mathrm{C}$ and $\mathrm{C}=\mathrm{O}$ of the unreacted chalcone moiety as indicated in Table 1.

Mechanism could be illustrated as follow:

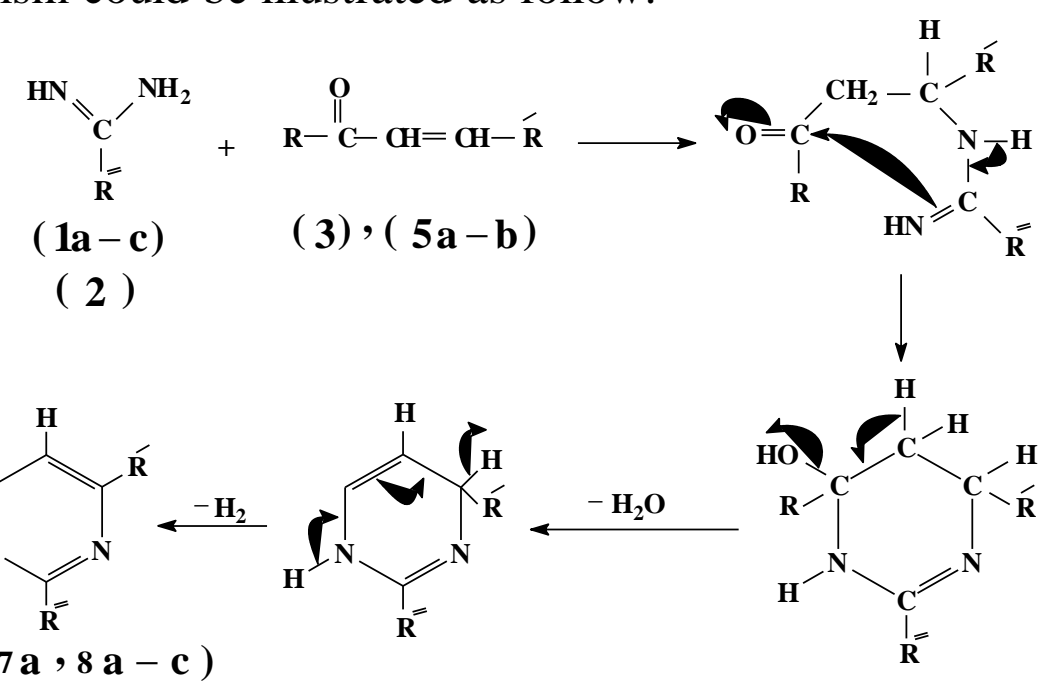

(9-11)

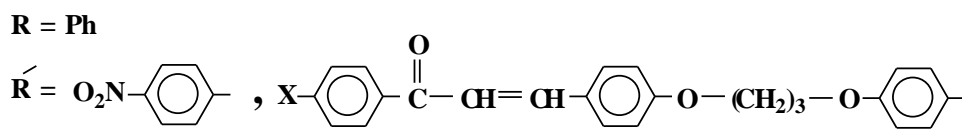

$$
\begin{aligned}
& \mathbf{R}^{\prime \prime}=\bigcup_{\mathbf{N}},-\mathrm{SC}_{2} \mathrm{H}_{5},-\mathbf{S C H}_{2} \mathrm{Ph},-\mathrm{SCH}_{2}-{ }_{0}
\end{aligned}
$$




\section{REFERENCES}

1. D. Azarifar and M. Shacbanzadeh, Molecules, (2002) 7885.

2. Craig M. Comisar and Phillip E. Savage, Green Chem., 2004, 6, 227-231, Dol: 10.1039/b314622g.

3. N. N. Agrawal and P. A. Soni, Indian Journal of Chemistry, (2004) 43B 2700.

4. N. R. Reddy and P. P. Reddy, Indian Journal of Chemistry, (2004) 43B 2165.

5. R.G. Vaghei, D. Azarifar and B. Malcki, Bull. Korean Chem. Soc., (2004) 25(7) 953.

6. A. A. El-Saied, M. A. El-Borai and M. A. Barren, Indian Journal of Chemistry, (2004) 43B 1355.

7. R. C. Maurya, A. Pandey and D. Sytradhar, Indian Journal of Chemistry, (2004) 43B 763.

8. S. Ferfra, N. H. Ahabchane, B. Garrigues and E. M. Essassi, Indian Journal of Chemistry, (2004) 43B 947.

9. V. Padmavthi, B. J. M. Reddy and D. R. C. V. Subbaiah, New J. Chem., (2004) 28, 1470.

10. V. Padmavathi, K. V. Reddy, M. R. Sarma, R. P. Sumathi and D. Bhaskar, Indian Journal of Chemistry, (2004) 43B 2236.

11. A. L. Marzinzik and E. R. Felder, J. Org. Chem., (1998) 63723.

12. A. R. Katritzky, J. Soloducho and S. Belyakov, Arkivok I, (2000) 38.

13. T. A. Naik and K. H. Chikhalia, E. Journal of Chemistry, (2007) 4(1) 60.

14. A. S. Tomcufcik, R. G. Wilkinson and R. G. Child, Ger. Pat., 2502490, 1975 (Chem. Abstr., 1975, 83, 179067n); K. Yamaguchi, Y. Sakurai and H. Kurumi, Jap. Pat., 4247016, 1972; (Chem. Abstr., 1972, 78, 97330d); A. Lespagnol, C. Lespagnol, D. Lesieur, J. P. Bonte, Y. Blain and O. Labian, Clin. Ther., 1971, 6, 192.

15. D. G. Powers, D. S. Casebier, D. Fokas, W. J. Ryan, J. R. Troth and D. L. Coffen, Tetrahedron, 1998, 54, 4085.

16. J. J. Donleary, J. Am. Chem. Soc., (1936) 581004.

17. J. J. Donleary, J. Am. Chem. Soc., (1936) 58141.

18. Kofod, Acta Chem. Scand., (1953) 71302.

19. R. Sandler and W. Kero, "Organic Functional Group Preparations", Academic Press Inc., London, Ltd., 1972 Vol, III.

20. A. Vogel, "Textbook of Practical Organic Chemistry", $4^{\text {th }}$ ed., Longman, London, 1978.

21. (a) B. Love and C. R. Dowson, J. Am. Chem. Soc., (1956) 786095.

(b) A. E. Vanstone, G. K. Mail and K. Lynn, U.S. Patent, (1989) Re.33 109.

22. A. J. Al-Hamdany and A. M. Al-Hamdany, J. Edu. \& Sci., (2006) $18,842-50$. 